СНЕЖКОВА Ирина Анатольевна - кандидат исторических наук, старший научный сотрудник Института этнологии и антропологии им. Н.Н. Миклухо-Маклая РАН (119334, Россия, г. Москва, Ленинский np-кm, 32A; snezhkova@ mail.ru)

\title{
СОВРЕМЕННАЯ КОНФЕССИОНАЛЬНАЯ СИТУАЦИЯ НА УКРАИНЕ: МЕЖКОНФЕССИОНАЛЬНЫЕ ПРОБЛЕМЫ И ПОИСКИ КОМПРОМИССОВ
}

Аннотация. Религиозная ситуация на Украине носит поликонфессиональный характер, поскольку страна находится на пути пересечения православия и католичества. В статье автор рассматривает, как политические разногласия отразились на религиозной жизни украинцев и с чем это связано. $B$ последнее время в связи с получением томоса от Константинополя отношения между Украинской православной церковью Московского патриархата и Православной церковью Украины, в недавнем прошлом - Украинской церковью Киевского патриархата, ухудшились. В работе дается характеристика автокефальной православной, грекокатолической, католической и протестантской церквей. Не обойдены вниманием мусульманские организации, иудейские, новые религии, неоязычники и восточные культы. Ключевые слова: конфессиональное разнообразие Украины, противоречия УПЦ МП, ПЦУ, томос, католики, мусульмане, иудейские организации, новые религии, неоязычники, восточные культы

$\Pi$ осле распада СССР во всех республиках наблюдался беспрецедентный рост числа религиозных организаций. По данным Государственного комитета Украины по делам национальностей и религий, на Украине насчитывалось более 30 тыс. религиозных объединений различного толка в сравнении с 4,5 тыс., которые существовали на ее территории в СССР. Если раньше к верующим себя относили $5 \%$ населения, то в настоящее время $-70 \%$. В особенности выросло число верующих среди молодежи и людей среднего возраста разных социальных слоев.

Религиозное поле Украины никогда не было моноконфессиональным. Религиозная конфигурация в исторической ретроспективе постоянно изменялась благодаря активной деятельности католической церкви. Большую роль сыграла Брестская уния 1696 г., разделившая украинцев на православных и греко-католиков. В советский период на Украине была развернута антирелигиозная кампания. Государственная политика воинствующего атеизма, особенно активная в первые годы советской власти и в хрущевский период, привела к сокращению численности верующих, уменьшению числа церквей. Оживление религиозной жизни наступило с началом перестройки. Помимо возрождения традиционных конфессий, появился такой феномен, как невоцерковленный верующий, который верит в существование Бога, Высшего разума, Абсолюта, но не примыкает к какой-либо религиозной организации и не посещает церковь.

Подавляющее большинство населения в Украине находится в лоне православных церквей - 54\% общего числа религиозных объединений, однако разделенность на разные течения порождает сложную ситуацию в конфессиональном поле страны. Три ветви православия конкурируют между собой - Украинская православная церковь Московского патриархата (далее -УПЦ МК), Православная церковь Украины (далее - ПЦУ), которая до получения томоса от Константинополя в конце 2018 г. именовалась Украинской православной церковью Киевского патриархата (далее - УПЦ КП) и Украинская автокефальная православная церковь (далее - УАПЦ). 
Самой многочисленной в православии является Украинская православная церковь Московского патриархата. С принятием томоса 2018 г. о переходе УПЦ КП под юрисдикцию Константинополя начался насильственный захват церквей УПЦ МП, поэтому данных последнего времени у нас нет. Ранее она имела 44 епархии, более 170 монастырей с 4,5 тыс. монашествующих, 20 духовных начальных учебных заведений, в которых обучались 3970 чел., 106 периодических изданий, 4158 воскресных школ и 34 братства [Колодний 2009: 73]. Управление церковью находится в Киево-Печерской лавре. Предстоятелем церкви является Митрополит Киевский и всея Украины Онуфрий. Наибольшая концентрация общин УПЦ МП наблюдается в Винницкой (916), Хмельницкой (898), Киевской с г. Киевом (860), Закарпатской (612), Ровенской (629), Волынской (614) областях [Україна релігійна 2008: 26]. УПЦ МП является самоуправляемой церковью с широкими правами автономии в составе Московской патриархии. Автономия была получена на Архиерейском соборе РПЦ в 1990 г. Положение УПЦ МП в настоящее время очень уязвимое. Несмотря на то что она обладает большинством приходов и прихожан на Украине, она все же зависима от политики государственной власти. Уже в период президентства В. Ющенко руководитель государства активно демонстрировал поддержку УПЦ КП во главе с патриархом Филаретом в качестве ведущей религиозной конфессии. При В. Януковиче положение в УПЦ МП стабилизировалось. В период правления П. Порошенко ей был нанесен сильный удар, практически легализовавший рейдерский захват храмов, принадлежащих Московскому патриархату. УПЦ МП активно дискредитировалась президентом П. Порошенко как московская церковь или как церковь «страны-агрессора», что позволило националистам, которые чаще всего не имеют никакого отношения к вере и к конкретным храмам, захватывать их и насильственно переводить в другую юрисдикцию.

Православная церковь Украины (ПЦУ), или до принятия томоса Украинская православная церковь Киевского патриархата (УПЦ КП), до недавнего времени насчитывала 31 епархию. Она имеет 45 монастырей с 136 насельниками, 16 духовных начальных училищ, 36 периодических изданий, 1234 воскресные школы, 9 братств. Кафедральным собором УПЦ КП является Владимирский собор в Киеве [Колодний 2009: 73]. Наибольшая численность УПЦ КП концентрируется в западных областях: Тернопольской (225), Волынской (320), Ивано-Франковской (290), Львовской (443), Ровенской (315) и Киевской с г. Киевом (465) областями [Україна релігійна 2008: 26]. Возглавлял церковь Патриарх Киевский и всея Руси - Украины Филарет. УПЦ КП не имела официального признания со стороны мирового православия и не находилась в евхаристическом общении ни с одной из канонических поместных православных церквей мира. Эта церковь возникла в результате объединения двух церковных групп, выступавших за полную независимость от Русской православной церкви (Московского патриархата): части националистически ориентированных представителей Украинской православной церкви Московского патриархата и Украинской автокефальной православной церкви. По мнению большинства православных церквей мира, она является раскольнической, по мнению Киевского патриархата - объединительной. Приверженцы УПЦ КП возводят ее историю к Киевской митрополии, находившейся в юрисдикции Константинопольской церкви, отрицая законность ее перехода под юрисдикцию Московского патриархата в 1686 г.

В настоящее время УПЦ КП делает акцент на предоставлении канонического перехода и объединения УПЦ МП и УПЦ КП для преодоления раскола и объединения церквей на Украине, но ни в одной из областей, кроме Галиции, Киевский патриархат не является доминирующей конфессией. УПЦ КП под- 
держивает активные отношения с Римско-католической церковью, грекокатолической церковью на Украине и Украинской православной автокефальной церковью. В настоящее время патриарх Филарет Денисенко находится под анафемой со стороны УПЦ МП и РПЦ МП. Личность патриарха Филарета очень спорная: еще в советское время он активно сотрудничал с КГБ, закрыл в Киеве духовную семинарию и был послушным исполнителем воли советских властей в ущерб церкви. Опираясь на свои заслуги перед светской властью, он претендовал на должность Патриарха всея Руси, но не был избран, после чего на Украине, получившей независимость в 1990-х гг., самовольно провозгласил себя Киевским патриархом.

Рассмотрим предысторию получения томоса, инициированного П. Порошенко в ходе подготовки к предвыборной кампании 2019 г., которую он все равно проиграл. В результате объединения с Константинополем была отменена автокефалия и независимость Киевского патриархата, полученная им еще в 1686 г. от Константинопольского патриарха. ПЦУ превратилась в митрополию, находящуюся под управлением Вселенского Константинопольского патриарха Варфоломея, резиденция которого находится в г. Стамбуле. Теперь решение всех важных вопросов новой церкви - канонических, кадровых, финансовых - будут происходить по согласованию с Константинополем. По форме это будет очень ограниченная в правах митрополия, не сравнимая по автономии и самостоятельности с УПЦ МП. На Украине решено передать 12 православных монастырей и церквей Константинопольской церкви. В последнее время бывший, или «почетный» Киевский патриарх Филарет вновь заявил свои права на патриаршество и обвинил ПЦУ в обмане. Самое печальное в этой истории то, что раскол усугубился как между православными на Украине, так и в среде мирового православия. В настоящее время ситуация находится в процессе трансформации, и многое зависит от нового президента В. Зеленского.

Украинская автокефальная православная церковь имела 1,2 тыс. религиозных организаций, 67\% которых находится в трех галицких областях Украины. Церковную службу в УАПЦ совершает 661 священник, в 7 духовных начальных училищах церкви обучаются 224 слушателя. В ней функционировали порядка 300 воскресных школ. В 6 монастырях находятся всего 12 насельников. УАПЦ также является церковью украинской диаспоры Северной Америки и Западной Европы. Зародилась УАПЦ после Февральской революции в результате движения за государственное и церковное отделение от России. Затем ее деятельность переместилась в Западную Европу и на Американский континент. Образовалась она в 1990 г. на Всеукраинском соборе автокефальной церкви. Официальную регистрацию в постперестроечное время получила в 1995 г. На службах поминается Константинопольский патриарх, но ее канонический статус не вполне урегулирован. Лозунг УАПЦ до недавнего времени был следующим: «Рим нам не батько, Москва - не мати. Хотим быть самостоятельными». $80 \%$ прихожан приходится на Львовскую, Ивано-Франковскую и Тернопольскую области. После принятия томоса началось активное сближение с ПЦУ. Ее деятельность проходит в русле национальной идеи и утверждения социально-культурных приоритетов украинской государственности.

В последние годы активно растет Украинская грекокатолическая церковь. В 2008 г. она имела 3685 религиозных организаций, что превысило довоенный уровень. Наибольшее число общин находится во Львовской (1478), Тернопольской (762), Ивано-Франковской (642) и Закарпатской областях (378). Руководит УГКЦ после ухода патриарха Любомира, кардинала Гузара, епископ Святослав Шевчук. В последнее время наблюдается расширение грекокато- 
лицизма в других регионах Украины. Церковь имеет 18 епархий и экзархатов, открыты 102 монастыря с 1269 монахами. В ее составе - 15 духовных училищ, 1163 воскресных школы, 28 периодических изданий. К этой церкви относятся также 19 грекокатолических епархий, которые функционируют среди украинской диаспоры за рубежом. В настоящее время управление грекокатолической церкви по политическим причинам перенесено в г. Киев, в связи с чем произошло удаление от основной паствы. УГКЦ является все-таки галицийским и закарпатским феноменом. Если в центре идет противоборство УПЦ МП и УПЦ КП (ПЦУ), то на западе Украины однозначно доминирует Украинская грекокатолическая церковь.

Среди традиционно существующих церквей страны можно назвать Римскокатолическую церковь. Во Львове находится ее центр, диэцезии (епархии) есть также в Житомирской, Луцкой, Каменец-Подольской областях. Действует духовный колледж, семинария и Украинский римско-католический университет. РКЦ имеет 91 монастырь с 700 насельниками, 517 воскресных школ, 14 периодических изданий и 541 священнослужитель, среди которых 251 - иностранцы. На Украине работают 39 миссий этой церкви и 3 братства.

Широко представлены на Украине церкви протестантского направления. Они имеют 8164 религиозные организации, что составляет $24 \%$ численности всех религиозных организаций страны, в т.ч. евангельские христиане баптисты - 3 025; христиане евангельской веры (пятидесятники) - 2 438; «свидетели Иеговы» - 1 032; адвентисты седьмого дня - 1 057; реформаторы - 118, лютеране - 101 и др.

Значительно возросло на Украине и число мусульманских организаций. На сегодняшний день в Киеве действуют 4 зарегистрированных самостоятельных центра: Духовное управление мусульман ДУМУ, Духовный центр мусульман Украины ДЦМУ и Киевский муфтият. До присоединения Крыма к России особое место занимало Духовное управление мусульман Крыма ДУМК. Последователями ислама на Украине являются представители национальных меньшинств - волжские татары, крымские татары, узбеки, абхазы и др. Однако большинство мусульманских общин объединяет крымских татар, которых на территории Украины стало значительно меньше после присоединения Крыма к России. Мусульмане на Украине имеют мечети, начальные училища и пятничные школы.

Шесть центров руководят иудейскими организациями (290). Среди них Объединение хасидов Хабад-Любавич, Всеукраинский конгресс иудейских религиозных организаций и др. Иудейские организации размещены по Украине равномерно. Выделяются Винницкая обл. (25) и г. Днепр (23), Донецкая (18), Хмельницкая (14), Закарпатская, Черновицкая (по 19), Черкасская (15) области и г. Киев (17). Существуют 7 иудейских начальных заведений, выходят 27 периодических изданий, действуют 72 субботние школы. В г. Днепре при участии олигарха И. Коломойского построена самая большая в Европе синагога. В последнее время в Израиле довольно активно поднимается вопрос о переселении части евреев на территорию Украины, т.к. в Израиле неспокойно в связи с мусульманским окружением, тяжелым жарким климатом, а в Украине, в частности в Умани, находятся захоронения почитаемых евреев-хабатников, к которым ежегодно совершается паломничество евреев со всего мира. Известно, что евреи-хабатники -наиболее активное на сегодняшний день направление в иудаизме.

В последние годы на Украине широкое распространение получили новые религии и течения. В 2008 г. были официально зарегистрированы 1895 организаций: среди них неохристиан - 1627 , неоориенталистов - 151, родноверов, 
которых официально именуют неоязычниками, - 116. Среди новых религиозных течений растут организации харизматического толка - их насчитывается 1 465. Их много в Запорожской области и в Киеве. В их число входят: церковь Полного Евангелия (595), новоапостольская церковь (59), церковь Иисуса Христа последних дней - мормонов (55), а также общество свидетелей Кришны (45), буддисты (54), бахаи (8) [Україна релігійна 2008: 26-29]. Функционируют различные родноверские направления, например родная вера, вера Великого огня. Общества новоапостолов, родноверов, кришнаитов, бахаев довольно равномерно распространены по всем областям Украины. Буддисты также распределились по всей Украине: они имеют организации в Харьковской, Запорожской и Киевской областях.

Из сказанного выше можно сделать следующие выводы. Конфессиональное разнообразие на Украине всегда существовало, периодически обострялись противоречия между православными, католиками, униатами. В настоящее время на Украине сохраняется неспокойная религиозная ситуация, спровоцированная политическим вмешательством в дела церкви команды предыдущего президента П. Порошенко, усилия которого были направлены прежде всего на отрыв Украинской православной церкви от Московского патриархата. Остается надеяться на здравый смысл нового украинского президента В. Зеленского, который не будет вмешивать государство в дела церкви и приведет страну к религиозному согласию.

\section{Список литературы}

Колодний А.М. 2009. Релігійне сьогодення України: роздуми, оцінки і прогнозі. АМ Колодний. Т. 100.

Україна релігійна: колективна монографія. Книга перша: Стан релігійного життя України (гол. ред. А. Колодний). 2008. К.: Українська Асоціація релігієзнавців, Відділення релігієзнавства Інституту філософії імені Г.С. Сковороди НАНУ. 436 с.

\section{THE CURRENT CONFESSIONAL SITUATION IN UKRAINE: INTERFAITH PROBLEMS AND SEARCH FOR COMPROMISES}

\footnotetext{
Abstract. The religious situation in Ukraine has been multi-confessional in nature, because it is on the way of crossing of Orthodoxy and Catholicism. The article analyzes how political differences have affected the religious life of Ukrainians and what its reasons. Recently, in connection with the receipt of Thomos from Constantinople, relations between the Ukrainian Orthodox Church of the Moscow Patriarchate and the Orthodox Church of Ukraine (in the recent past - the Ukrainian Church of the Kyiv Patriarchate) have worsened. The paper describes the autocephalous Orthodox Greek, Catholic, Catholic and Protestant churches, Muslim and Jewish organizations, as well as new religions, neo-Pagans and oriental cults. Keywords: confessional diversity in Ukraine, contradictions of UOC MP, OCU, Catholics, Thomos, Muslims, Jewish organizations, new religions, neo-Pagans, oriental cults
} 